International Journal of Instruction e-ISSN: 1308-1470 • www.e-iji.net
October $2017 \bullet$ Vol.10, No.4

p-ISSN: 1694-609X

pp. $67-86$

Received: 03/04/2017

Revision: 10/06/2017

Accepted: 15/06/2017

\title{
Use of Interactive Whiteboard in the Mathematics Classroom: Students' Perceptions within the Framework of the Technology Acceptance Model
}

\author{
Nezih Önal \\ Asst. Prof., Omer Halisdemir University, Turkey, nezihonal@ohu.edu.tr
}

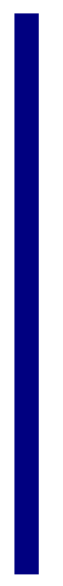

\begin{abstract}
The purpose of the present research was to reveal students' perceptions regarding the use of the interactive whiteboard in the mathematics classroom within the framework of the Technology Acceptance Model. Semi-structured interviews were performed with 58 secondary school students (5th, 6th, 7th, and 8th grades) to collect data. The data obtained were encoded and interpreted using the content analysis technique within the framework of the Technology Acceptance Model-3 components. Students' perceptions were divided into categories of perceived ease of use, perceived usefulness and perceived negativities, which were names created by the researcher. Based on the findings, it was revealed that the participants had positive perceptions of the use of the interactive whiteboard in the mathematics classroom. Specifically, they found it beneficial because it enabled students to better understand the course, enabled students to be engaged in a meaningful learning and effectual engagement in the classroom, increased students' concentration, and saved time. It was concluded that the participants found the use of the interactive whiteboard useful and easy. Thus, they accepted this technology.
\end{abstract}

Keywords: mathematics, interactive whiteboard, technology acceptance model (TAM), mathematics classroom, students

\section{INTRODUCTION}

In Turkey, primary and secondary school students fear mathematics and experience anxiety in learning mathematics, often leading to failure in mathematics. This failure can be exemplified by low averages of mathematics scores in international exams, such as the Exam for Transition from Primary to Secondary Education (TPSE), Program for International Student Assessment (PISA) and Trends in International Mathematics and Science Study (TIMSS). In the updated instructional program of secondary school mathematics (Ministry of National Education, MNE, 2013), mathematics instruction is addressed as an active process, and it is emphasized that students should play the role of an active participant in the learning process. Hence, learning environments need to be established to enable students to investigate and question things, build effective communications, think critically, share their opinions and offer different methods of

Citation: Önal, N. (2017). Use of interactive whiteboard in the mathematics classroom: Students' perceptions within the framework of the Technology Acceptance Model. International Journal of Instruction, 10(4), 67-86. https://doi.org/10.12973/iji.2017.1045a 
solutions. Another area that should also be encouraged in the instructional program is the efficient use of information and communication technologies in mathematics instruction and learning.

The vision of the Turkish educational system regarding the information technologies specified by MNE (2013, p.1) is "To integrate advanced technologies with the educational system, support it with innovations, evaluate it to improve permanently, and achieve a student-centered and project-based education by using information technologies." It is especially emphasized that information and communication technologies which enable students to explore mathematical relations should be utilized and 'such environments should be created to improve students' skills such as problemsolving, communicating, reasoning, etc. through modeling" (MNE, 2013, p.1).

Accordingly, it has been planned together with the Movement of Enhancing Opportunities and Improving Technology, which is a project by MNE, to equip more classrooms with tablet PCs and interactive whiteboards and to ensure that information and communication technologies are used by students and teachers efficiently. This is because it is obvious that several changes should be made in the learning and teaching process for the new generation learners, who have means to access information instantly and regard smartphones as part of their lives. Making use of these information and communication technologies, which are regarded as an indispensable component of their lives, may contribute to the teaching and learning of mathematics to the new generation learners who have maths anxiety. Consequently, children today need to learn how to use current methods and technologies.

Tablet PCs and interactive whiteboards, which have become popular tools in education instruction with the project FATIH, which was initiated in 2010 in Turkey, continue to be utilized in the classrooms to facilitate teaching. The plan of the project is based on equipping classrooms at all stages of education (high school, secondary school, primary school and preschool) with internet-connected computers, interactive whiteboards and projectors (Adıgüzel, Gürbulak \& Sarıçayır, 2011). Even though the proliferation of those technologies is not at a desired level, it is necessary and important to benefit efficiently from tablet PCs, interactive whiteboards, and several cloud-based applications in education in general and in mathematics instruction in particular. Using these technologies, course contents, images, animations or simulations, which can be found on the Internet, can be utilized to enhance the quality and effectiveness of the instruction. The use of appropriate software technologies, especially in mathematics lessons, may be beneficial for meaningful learning (Önal, 2014).

Hew and Brush (2007) described technological integration in education as the use of all kinds of technologies by teachers in learning and teaching activities to increase student achievement. The view that integration of technologies contribute to the learning and teaching process is widespread. Furthermore, there are certain factors in the mechanisms of accepting and deciding to use technology for individuals. It is possible to explain these factors by means of the Technology Acceptance Model (TAM), which is a technological integration model developed by Davis (1989). TAM is a model based on the view that individuals make decisions in reference to the benefit they perceive in the 
related technology and the ease of using that technology in the processes of accepting a technology and deciding to use it.

Davis' TAM (1989) has been broadened and updated through several studies and mentioned in the literature in various forms, namely the Technology Acceptance Model 2 (Venkatesh \& Davis, 2000) and the Unified Theory of Acceptance and Use of Technology (Venkatesh, Morris, Davis \& Davis, 2003). TAM was revised and broadened even further in several research studies (Venkatesh \& Bala, 2008), leading to the development of Technology Acceptance Model 3 (TAM3). The variables of perceived ease of use, perceived usefulness, behavioral intention, and usage behavior remained important as basic structural variables in TAM3 just like in the original model. The relationships between these variables and the effects of certain external factors creating these variables were studied in TAM3. By this means, it was planned to estimate individuals' actual behaviors for using any technology (Davis et al., 1989). In short, according to TAM, when individuals believe that technology can be used easily, they also tend to believe that it is a useful technology. In addition, the higher the level of individuals' intention is towards using a technology, the easier it is for them to use technology and the more useful they find that technology. The possibility that individuals with stronger intentions to use technology utilize that technology in their real lives increases (Davis, 1989).

There are various research studies on TAM performed with different age groups. Most of the research studies in the literature were based on quantitative methods ( $\mathrm{Ng}$, Shroff, \& Lim, 2013; Ma, Andersson \& Streith, 2005; Teo, 2009; Teo, 2010; Teo, Ursavaş \& Bahçekapıl1, 2012; Turan \& Çolakoğlu, 2008; Ursavaş, 2014; Ursavaş, Şahin \& Mcilroy, 2014). For instance, a study by Ma, Andersson and Streith (2005) on the acceptance of computer technologies by teacher candidates reports that the perceived ease of use and perception of usefulness are extremely effective in the intention to use a computer. Teo (2009) stated that perceived usefulness has a direct impact on teacher candidates' attitudes towards and self-efficacies in computer use, but facilitators indirectly influence technology acceptance. Some studies which are based on qualitative research methods have examined the opinions of academicians, teachers and administrators in accordance with the TAM components (Menzi, Önal \& Çalıskan, 2012; Görhan \& Öncü, 2015). In their study with teachers and school administrators on the perceived ease of use and the perceived usefulness of the interactive whiteboard by using TAM-3, Görhan and Öncü (2015) found that the interactive whiteboard was problematic in terms of security and asserted that users had certain difficulties due to oversensitivity of the touch screen. Yet, in the same research, interactive whiteboard enabled the users to use the time efficiently and had the potential to enrich the learning process. The results showed that the participants found interactive whiteboards to be useful but difficult to use.

Some research studies in the related literature report that the use of interactive whiteboard contributes to learning and teaching processes and is more advantageous than the use of plain whiteboards (Beauchamp, 2004; Bunch, Robinson \& Edwards, 2012; Cogill, 2002; Çoklar \& Tercan, 2014). In each study on the subject, however, 
teachers' opinions have been sought in general to evaluate the use of the interactive whiteboard in classrooms (Beauchamp, 2004; Bilici, 2011; Keser \& Çetinkaya, 2013; Lau, 2011). It is also critical to gain insight into the opinions and thoughts of students who are the ones who are in direct confrontation with the use of the interactive whiteboard in classrooms and are literally the subject of interactive whiteboards. Thus, that the present research was conducted with students is of significance. Turkey's educational policies regarding the use of the interactive whiteboard in classrooms can be reviewed in accordance with the findings obtained in this research. Based on these findings, samples of greater sizes can be reached out to and the status of those samples can be identified to enhance and revise those policies. The results to be obtained can also provide important considerations for teachers who are basically the practitioners of instructional programs and the technological integration in education.

In the present research, the factors that determine students' levels of accepting the interactive whiteboard, which is becoming increasingly popular at schools in Turkey with the project FATIH, were examined within the framework of TAM3 (Venkatesh \& Bala, 2008). TAM3, which is constituted by the basic components of Perceived Usefulness, Perceived Ease of Use, Behavioral Intention and Usage Behavior, and Individual Differences, System Characteristics, Social Influence and Facilitating Conditions, which affect those components, are presented in Figure 1.

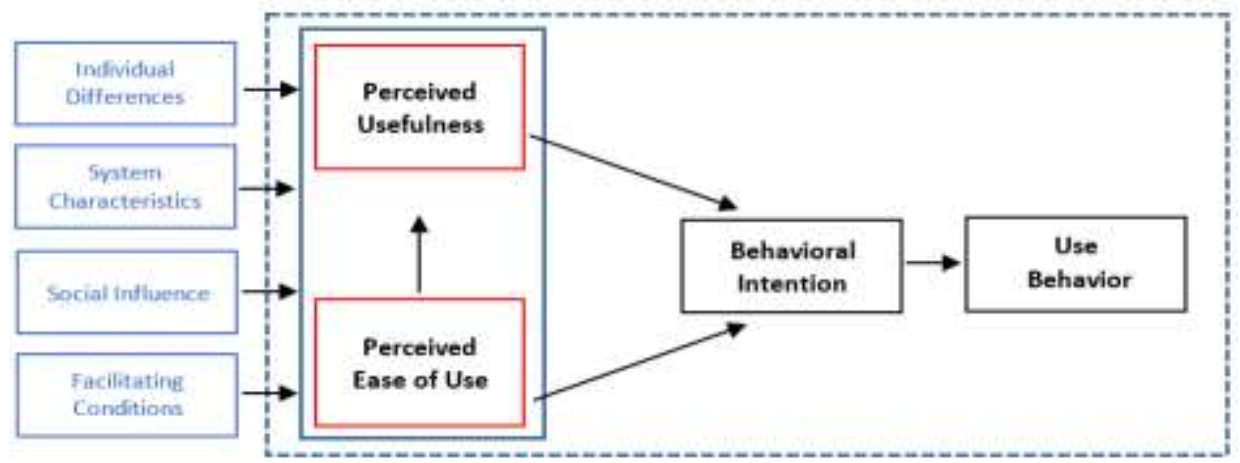

Figure 1

Technology acceptance model-3 (Venkatesh \& Bala, 2008)

The research emphasizes the use of the interactive whiteboard in the mathematics classroom, which often requires solving problems on the whiteboard. Students' opinions regarding the use of the interactive whiteboard in the mathematics classroom were formed based on the effects of certain external factors, which lead to the basic components of TAM3, namely Perceived Usefulness and Perceived Ease of Use and others. Another category was added after the encoding of the data obtained from the research group under the name of Perceived Negativities, which are likely to play an effective role in behavioral intention, and therefore, usage behaviors. From this point of view, the research question can be stated as follows: "What are secondary school students' perceptions regarding the use of the interactive whiteboard in the mathematics classroom?" 


\section{METHOD}

\section{Research Design}

The research method employed in the current study was the case study model, which is a qualitative research method (Yıldırım \& Şimşek, 2008). The case study model was preferred because it provides the researcher with the chance to examine the case in question in depth through the questions "how" and "why" (Yin, 2003). Case studies, according to Merriam (1998), are studies conducted by focusing on a "specific case, event, program or phenomenon." Case study is considered as one of the best ways to achieve intensive definitions and analyses of a single unit or a system limited to an individual, a program or a group (Merriam, 1998). In the present research, a group of secondary school students were asked for their opinions regarding the use of the interactive whiteboard.

\section{Participants}

The data were obtained from the students in 5th, 6th, 7th and 8th grades $(\mathrm{N}=58)$ who were attending a state secondary school affiliated to the Ministry of National Education. Demographic information of the students is given in Table 1 below.

Table 1

Demographic information of the students in the study group

\begin{tabular}{llll}
\hline \multicolumn{1}{c}{ Demographic Information } & & $\mathrm{N}$ & $\%$ \\
\hline \multirow{2}{*}{ Gender } & Female & 36 & 62.07 \\
& Male & 22 & 37.93 \\
\hline \multirow{3}{*}{ Grade level } & $5^{\text {th }}$ Grade & 15 & 25.86 \\
& $6^{\text {th }}$ Grade & 13 & 22.41 \\
& $7^{\text {th }}$ Grade & 20 & 34.48 \\
& $8^{\text {th }}$ Grade & 10 & 17.24 \\
\hline
\end{tabular}

The researcher utilized the criterion sampling method, which is a purposive sampling method, in accordance with the objectives of the case study. The criterion for the sample selection was being a state school that was using interactive whiteboards in its classrooms within the scope of the project FATIH.

The researcher started collecting data from students in different grades, and interviews ended when data were eventually collected from 58 students. Data were collected from 58 students in the present research to reveal the opinions of students at different grade levels.

\section{Data Collection}

Data in the present study were collected by means of interview questions. The aim of the questions posed by the researcher in the interview sheet was to reveal students' opinions regarding the use of the interactive whiteboard in the mathematics classroom. The questions were as follows:

(1) How did using the interactive whiteboard affect your interest in mathematics? Can you explain why you think so?; (2) What do you think the positive/useful and 
negative/harmful aspects of using the interactive whiteboard in the mathematics classroom are?; (3) Which do you think is more useful in terms of going to the whiteboard to solve mathematical problems: the interactive whiteboard or the whiteboard? Can you explain your reasons?; (4) How does using the interactive whiteboard affect your mathematics learning process?

\section{Analysis of Data}

Within the scope of this study, the interview forms administered to the students were checked one by one and numbered starting from 1. Each interview transcript was given a code (S1, S2....S58), and the findings were presented under those codes so that the students' names would not be disclosed in the research. The analysis was performed by means of encoding using the open coding method described as the "effort to reveal the meaning within the pieces of data (text, sentence, and paragraph) by questioning them" (Berg, 2001). The data obtained in the research were analyzed by the researcher and a mathematics teacher. Separate encodings were performed by the two experts, and a consensus was reached on some codes. The results obtained in both analyses were examined in detail and carefully, their underlying meanings were discussed, and they were categorized under certain themes with 100-percent consensus.

To achieve validity and reliability in case studies, it is recommended that the researcher extend the time he/she remains within the "case" studied. At the end of the research, the researcher shared the main results with the participants and took their opinions to describe the case as accurate and impartial as possible. This is one of the precautions taken to ensure the validity and reliability of the research. Finally, the researcher received expert opinion from a researcher working in the same field about how accurate the results obtained were since this can enable the results to be supported and alternative explanations to be made for the results (Merriam, 1998).

To ensure the validity of the study, how the research was conducted and the data were collected were explained, and the data obtained were reported in detail. Moreover, a precaution was taken for the validity of the research by citing directly from the participants when reporting the results (Yıldırım \& Şimşek, 2008).

In addition to increase reliability in a case study, the researcher needs to define the processes followed, support them with related documents, develop the research gradually and systematically and report it. The researcher also needs to create a database that can be utilized by others so that the research can be replicated (Yin, 2003). To determine the consistency of separate encodings by the two researchers, the answers to each question obtained from the analyses of the interview responses were handled and compared one by one.

\section{FINDINGS}

The research findings were coded based on the components of TAM3, namely Perceived Ease of Use and Perceived Usefulness. Yet, another category named Perceived Negativities was created using the data obtained. All the data were presented in three categories and under several themes.

Perceived Ease of Use 
Based on the answers given to the questions, student opinions were gathered under three themes in TAM3: (1) Facilitating Conditions, (2) System Characteristics, and (3) Individual Differences. These themes are presented in Table 2.

Table 2

Codes and Themes Regarding the Perceived Ease of Use for the Use of Interactive Whiteboards

\begin{tabular}{|c|c|c|c|}
\hline Theme & Code & Students $\left(5^{\text {th }}-6^{\text {th }}-7^{\text {th }}-8^{\text {th }} \text { grades }\right)^{*}$ & $\begin{array}{c}\text { Code } \\
\text { Number (f) }\end{array}$ \\
\hline \multirow{6}{*}{$\begin{array}{l}\text { Facilitating } \\
\text { Conditions }\end{array}$} & Using video and internet images & $\begin{array}{l}\text { S1, S6, S13, S17, S19, S23, S28, S30, } \\
\text { S34, S45 }\end{array}$ & 10 \\
\hline & $\begin{array}{l}\text { Loading the course sources } \\
\text { (books, tests...) on the interactive } \\
\text { whiteboard }\end{array}$ & $\begin{array}{l}\text { S5, S13, S17, S18, S33, S34, S36, } \\
\text { S39 }\end{array}$ & 8 \\
\hline & Facilitating the teacher's job & $\mathrm{S} 1, \mathrm{~S} 2, \mathrm{~S} 3, \mathrm{~S} 6, \mathrm{~S} 10, \mathrm{~S} 13$ & 6 \\
\hline & $\begin{array}{l}\text { Accessing different sources easily } \\
\text { via internet }\end{array}$ & $\mathrm{S} 18, \mathrm{~S} 36, \mathrm{~S} 38, \mathrm{~S} 39, \mathrm{~S} 40$ & 5 \\
\hline & Facilitating the course work & $\mathrm{S} 1, \mathrm{~S} 2, \mathrm{~S} 3, \mathrm{~S} 14, \mathrm{~S} 15$ & 5 \\
\hline & Drawing geometric shapes easily & S32, S36, S45, S57 & 4 \\
\hline \multirow{3}{*}{$\begin{array}{l}\text { System } \\
\text { Characteristics }\end{array}$} & Visual and voice effect & $\begin{array}{l}\text { S1, S4, S7, S8, S12, S18, S21, S23, } \\
\text { S27, S28, S29, S30, S42, S43, S51, } \\
\text { S54, S55, S56, S57 }\end{array}$ & 19 \\
\hline & Not requiring pen, ink, chalk & $\begin{array}{l}\text { S1, S3, S4, S6, S12, S16, S18, S19, } \\
\text { S20, S30, S39, S43, S46, S52 }\end{array}$ & 14 \\
\hline & Use of touch screen like tablets & S7, S15, S25, S28, S49, S50, S52 & 7 \\
\hline \multirow{3}{*}{$\begin{array}{l}\text { Individual } \\
\text { Differences }\end{array}$} & $\begin{array}{l}\text { Easy and convenient writing and } \\
\text { erasing }\end{array}$ & $\begin{array}{l}\text { S1, S2, S4, S8, S9, S10, S14, S21, } \\
\text { S37, S38, S41, S43, S47, S49, S50, } \\
\text { S51 }\end{array}$ & 16 \\
\hline & Fast writing & S1, S5, S6, S12, S16, S17, S23 & 7 \\
\hline & $\begin{array}{l}\text { Less need to write in the } \\
\text { notebook }\end{array}$ & $\mathrm{S} 21, \mathrm{~S} 39, \mathrm{~S} 40, \mathrm{~S} 44, \mathrm{~S} 46, \mathrm{~S} 47$ & 6 \\
\hline \multicolumn{3}{|c|}{$* 5^{\text {th }}$ grade $=\mathrm{S} 1, \mathrm{~S} 2, \ldots \mathrm{S} 15, * * \mathbf{6}^{\text {th }}$ grade $=\mathrm{S} 16, \mathrm{~S} 17, \ldots \mathrm{S} 28, * * * 7^{\text {th }}$ grade $=\mathrm{S} 29, \mathrm{~S} 30, \ldots \mathrm{S} 48, * * * \boldsymbol{8}^{\text {th }}$ grade $=\mathrm{S} 49, \mathrm{~S} 50, \ldots \mathrm{S} 58$} & 107 \\
\hline
\end{tabular}

Perceived ease of use is described as individuals' belief in using a system (or a technology) effortlessly (Davis et al., 1989). What is meant with the perceived ease of use in this research is to reveal students' thoughts on what conveniences the use of interactive whiteboard in the mathematics classroom can provide.

According to TAM3, efficient technological integration is quite important for perceived ease of use. The ease of use perceived by the students who participated in the interviews for the use of the interactive whiteboard was encoded within the framework of the answers given to the interview questions. As seen in Table 2, the students reported under the theme facilitating conditions that the interactive whiteboard allows the use of videos and internet images and the books, activities, problems and tests they use in the classroom are saved on the whiteboard. In addition, some of the students stated that interactive whiteboards facilitate the job of their teachers, they use the whiteboard to access different course sources and types of questions via the internet, and they find it very convenient when drawing geometric shapes in the mathematics classroom and the interactive whiteboard facilitates the classroom. Some of the student opinions forming the facilitating conditions in the research were exemplified as follows: 
S1: "We can easily solve the problems on the smart whiteboard and it facilitates our classes. We can analyze the research questions and watch an instructive video in the class. Without the smart whiteboards, we couldn't watch videos or do research with the traditional boards. And chalks used to be broken all the time. We can do it all now. The teacher can easily open the pictures on the smart whiteboard..."

S18: "We can find the necessary information on the smart whiteboard in a faster way. We can find the subjects of the course. And we can open the same textbook with ours on the smart whiteboard."

S40: "We can solve the problems in our textbook in a more detailed way on the smart whiteboard. And we can also solve other problems on the smart whiteboard via the internet. We can benefit from other sources. We don't have to write down the questions. We come by many types of questions."

S57: "We comprehend the subjects related to geometric shapes in mathematics more easily and conveniently."

Another theme in the present study was the system characteristics. The codes that emerged under this theme were the easiness and benefits provided by the interactive whiteboard system. Accordingly, opinions that students held in that the interactive whiteboard was easy to use because it provides visual and voice effect and does not require a pen, ink, and chalk, and has a touch screen like tablets were gathered under the theme of system characteristics. Some of the student opinions forming the system characteristics in the research were exemplified as follows:

S7: "The smart whiteboard made me concentrate better. Colors and shapes look livelier. Its resemblance to tablet PCs makes it easier for us. We can solve more questions."

S52: "I think one of the positive aspects of the interactive whiteboard is that we don't get to use a pen. We don't use ink."

S30: "I think the interactive whiteboard is better than a plain whiteboard. We run out of the pen when writing on the plain whiteboard and it affects us negatively. But the smart whiteboard has a single pen. And it doesn't run out. That's why it is more advantageous for us than the plain one."

Student opinions on the use of interactive whiteboard in the mathematics classroom may also vary by their individual differences (psychomotor skill differences as well as cognitive differences of students). It is possible to state under the individual differences theme that they find it easy and convenient to write and erase on the interactive whiteboard; whiteboards allow students to write faster or it makes them write in the notebook less frequently, thereby enabling them to follow the lesson better. Some of the student opinions forming the individual differences in terms of the perceived ease of use were exemplified as follows:

S51: "The interactive whiteboard is more useful, easier and more practical than the plain whiteboard because it is harder to write and erase things on the plain whiteboard; an interactive whiteboard is more helpful and simpler." 
S43: "I like mathematics better with the use of the smart whiteboard in the mathematics classroom. I think using a smart whiteboard is helpful. We couldn't make the questions fit on the plain whiteboard. The ink would run out. We would buy a new one each week. These problems ended thanks to the interactive whiteboard. It is easier to use this whiteboard. For example, it used to be harder to erase writings on the plain one. But you can erase all of them with one button on the smart whiteboard. The questions can be zoomed in and you can move on to an empty page.

\section{Perceived Usefulness}

According to the students' opinions, perceived usefulness can be combined under three main themes of TAM3: (1) Individual Differences, (2) Social Influence, and (3) System Characteristics. These themes are presented in Table 3.

Table 3

Codes and Themes Regarding the Perceived Usefulness for the Use of Interactive Whiteboards.

\begin{tabular}{|c|c|c|c|}
\hline Theme & Code & Students $\left(5^{\text {th }}-6^{\text {th }}-7^{\text {th }}-8^{\text {th }} \text { grades }\right)^{*}$ & $\begin{array}{l}\text { Code Number } \\
\text { (f) }\end{array}$ \\
\hline \multirow{6}{*}{$\begin{array}{l}\text { Individual } \\
\text { Differences }\end{array}$} & $\begin{array}{l}\text { Understanding the course } \\
\text { better }\end{array}$ & $\begin{array}{l}\text { S1, S2, S3, S4, S6, S8, S11, S12, S17, } \\
\text { S19, S22, S24, S25, S26, S28, S29, } \\
\text { S30, S40, S41, S42, S43, S45, S46 }\end{array}$ & 23 \\
\hline & Comprehending faster & $\begin{array}{l}\mathrm{S} 29, \mathrm{~S} 30, \mathrm{~S} 32, \mathrm{~S} 35, \mathrm{~S} 39, \mathrm{~S} 41, \mathrm{~S} 42 \\
\mathrm{~S} 43, \mathrm{~S} 45, \mathrm{~S} 58\end{array}$ & 10 \\
\hline & $\begin{array}{l}\text { Learning in a meaningful } \\
\text { way }\end{array}$ & $\begin{array}{l}\text { S5, S11, S12, S50, S52, S54, S56, S57, } \\
\text { S58 }\end{array}$ & 9 \\
\hline & $\begin{array}{l}\text { Concentrating on } \\
\text { motivation in the class }\end{array}$ & S1, S4, S5, S7, S8, S26, S41, S42, S43 & 9 \\
\hline & Increase in achievement & S27, S28, S41, S48 & 4 \\
\hline & $\begin{array}{l}\text { Facilitating self- } \\
\text { development }\end{array}$ & $\mathrm{S} 31, \mathrm{~S} 34, \mathrm{~S} 42$ & 3 \\
\hline \multirow{4}{*}{ Social Influence } & $\begin{array}{l}\text { Facilitating efficient } \\
\text { engagement }\end{array}$ & $\begin{array}{l}\text { S5, S6, S7, S9, S11, S20, S22, S24, } \\
\text { S29, S32, S44, S50, S53 }\end{array}$ & 13 \\
\hline & $\begin{array}{l}\text { Bringing in positive } \\
\text { attitude towards the class }\end{array}$ & $\begin{array}{l}\text { S4, S5, S6, S8, S10, S11, S12, S14, } \\
\text { S32, S43, S45, S47 }\end{array}$ & 12 \\
\hline & $\begin{array}{l}\text { Increasing the willingness } \\
\text { to go to the whiteboard }\end{array}$ & $\begin{array}{l}\text { S1, S5, S7, S8, S12, S29, S32, S33, } \\
\text { S34, S35, S43, S44 }\end{array}$ & 12 \\
\hline & $\begin{array}{l}\text { Making the class more } \\
\text { fun and enjoyable }\end{array}$ & $\begin{array}{l}\text { S20, S25, S26, S29, S30, S31, S35, } \\
\text { S41, S42, S57 }\end{array}$ & 10 \\
\hline \multirow{4}{*}{$\begin{array}{c}\text { System } \\
\text { Characteristics }\end{array}$} & $\begin{array}{l}\text { Facilitating solving more } \\
\text { problems }\end{array}$ & $\begin{array}{l}\text { S1, S3, S4, S5, S6, S7, S8, S9, S12, } \\
\text { S13, S18, S19, S20, S21, S23, S24, } \\
\text { S49, S55, S52, S53, S58 }\end{array}$ & 21 \\
\hline & Being time saving & $\begin{array}{l}\text { S } 9, \text { S } 13, S 15, S 17, S 34, S 38, S 39, S 42, \\
\text { S43, S44, S46, S47, S48, S51, S53 }\end{array}$ & 15 \\
\hline & Attractiveness & $\begin{array}{l}\mathrm{S} 16, \mathrm{~S} 19, \mathrm{~S} 20, \mathrm{~S} 21, \mathrm{~S} 29, \mathrm{~S} 32, \mathrm{~S} 34 \\
\mathrm{~S} 36, \mathrm{~S} 42, \mathrm{~S} 45, \mathrm{~S} 47, \mathrm{~S} 49, \mathrm{~S} 50, \mathrm{~S} 51\end{array}$ & 14 \\
\hline & $\begin{array}{l}\text { Facilitating solving } \\
\text { problems in detail }\end{array}$ & $\begin{array}{l}\mathrm{S} 8, \mathrm{~S} 10, \mathrm{~S} 29, \mathrm{~S} 30, \mathrm{~S} 31, \mathrm{~S} 33, \mathrm{~S} 36, \mathrm{~S} 39 \\
\mathrm{~S} 40, \mathrm{~S} 43, \mathrm{~S} 44, \mathrm{~S} 45, \mathrm{~S} 46, \mathrm{~S} 48\end{array}$ & 14 \\
\hline \multicolumn{3}{|c|}{$\begin{array}{l}* 5^{\text {th }} \text { grade }=\mathrm{S} 1, \mathrm{~S} 2, \ldots \mathrm{S} 15, * * \mathbf{6}^{\text {th }} \text { grade }=\mathrm{S} 16, \mathrm{~S} 17, \ldots \mathrm{S} 28, * * * 7^{\text {th }} \text { grade }=\mathrm{S} 29, \mathrm{~S} 30, \ldots \mathrm{S} 48, * * * * \mathbf{8}^{\text {th }} \text { grade }=\mathrm{S} 49 \\
\mathrm{~S} 50, \ldots \mathrm{S} 58\end{array}$} & 169 \\
\hline
\end{tabular}


Perceived usefulness is defined as individuals' belief in that a technology or system will enhance professional performance and productivity (Davis et al., 1989). For example, not waiting in the queue is a perceived usefulness of an individual who pays the phone bill by means of automatic payment order via the internet instead of going to the bank. The perceived usefulness in the present research refers to students' beliefs as to what extent using the interactive whiteboard in the mathematics classroom will improve their achievements.

According to TAM3, efficient technological integration depends on the perceived usefulness as well as the perceived ease of use. Subsequently, individuals' belief in that interactive whiteboards will provide an important benefit to learning and teaching is considered significant for them to integrate the interactive whiteboard with learning and teaching processes (Hew \& Brush, 2007). In this sense, usefulness perceived by the students who participated in the interviews for the use of the interactive whiteboard were coded within the framework of the answers given to the interview questions. As can be seen in Table 3, the students believe that interactive whiteboard makes them understand the course better, and comprehend the subjects taught faster; it provides meaningful learning, concentration on the course and allows for self-development. In this research, some of the student opinions forming the individual differences theme were exemplified as follows:

S3: "The interactive whiteboard increased my interest in the mathematics class. I can solve and understand the problems better. I can solve the question which I couldn't before."

S42: "It helps us comprehend the mathematics class better. We are more careful now. I can reinforce the subjects. It's good that we have an interactive whiteboard. I'm more motivated towards my classes."

S41: "It had a positive impact. The mathematics is more fun now. I started to better understand the subjects, which I couldn't before in the mathematics classroom. This will contribute well to my mathematics marks. An interactive whiteboard is a good idea. It's easy to use and we can solve questions on our own."

S35: "I find mathematics more fun with the interactive whiteboard now. I can comprehend the subjects in a better way."

Some of the students also reported that the interactive whiteboard has a social influence. For example, they stated that the use of the interactive whiteboard in the mathematics classroom provides students with effectual engagement in the class, enables students to display positive attitudes towards the class and motivates students to go to the whiteboard, solve problems and touch the whiteboard. Some of the student opinions coded under the social influence theme in the research were exemplified as follows:

S28: "I think it's better now. I somehow listen to the teacher better with the help of the interactive whiteboard. I think I'm better in mathematics now. I go to the whiteboard more frequently now. 
S50: "My interest in the courses increased, and I think I listen to the teacher more efficiently in the classroom. I want to go to the interactive whiteboard and solve the problems on my own. Now it is more fun to solve problems on the interactive whiteboard..."

S48: "Using the interactive whiteboard in the mathematics classroom affected my interest towards the lesson. It helps me raise my hand to go to the whiteboard and made me more eager to participate in the class."

Some of the student opinions forming the system characteristics in the research were exemplified as follows:

S49: "We're doing more tests on the smart whiteboard. The positive side of the smart whiteboard is that we can both review the subject and solve questions right after."

S38: “...Instead of writing a question in the textbook on the plain whiteboard, we open the question on the interactive whiteboard more quickly and save time. We can also access the sources fast, upscale and downscale the writing easily."

S39: "I would have to write on the plain whiteboard in the mathematics classroom. But we can solve more problems and learn without writing much with the smart whiteboard. We can directly open the questions in our test books on the smart whiteboard."

S58: "Interactive whiteboard is much more advantageous in terms of question diversity.

The chart in Figure 2 was prepared with the answers given by the students regarding the question about which type of whiteboard they preferred in the mathematics classroom in general.

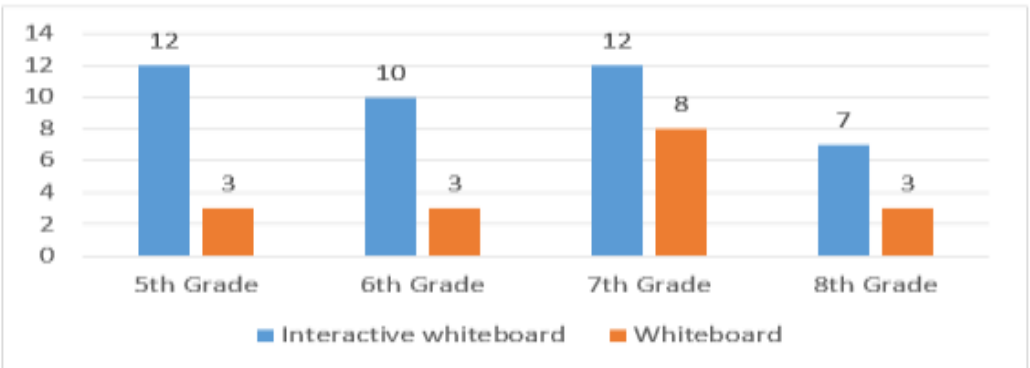

Figure 2

Students' preferences regarding the use of the whiteboard in the mathematics classroom

As can be seen in Figure 2, 41 out of 58 students who participated in the research preferred using the interactive whiteboard, while 17 of them preferred using a plain whiteboard for several reasons. When they were asked for an explanation, they mentioned the negative aspects of an interactive whiteboard in general. Based on such opinions of the students, a new category named Perceived Negativities was created by the researcher besides the two main components of TAM3. 


\section{Perceived Negativities}

Table 4 presents the category of Perceived Negativities in themes formed by combining the negative opinions obtained from the codes.

Table 4

Codes and Themes Regarding the Perceived Negativities for the Use of Interactive Whiteboards.

\begin{tabular}{|c|c|c|c|}
\hline Theme & Code & Students $\left(5^{\text {th }}-6^{\text {th }}-7^{\text {th }}-8^{\text {th }} \text { grades }\right)^{*}$ & $\begin{array}{c}\text { Code } \\
\text { Number (f) }\end{array}$ \\
\hline \multirow{3}{*}{$\begin{array}{l}\text { Health } \\
\text { Problems }\end{array}$} & Health hazards to the eye & $\begin{array}{l}\text { S1, S2, S6, S7, S8, S9, S10, S12, S15, } \\
\text { S26, S31, S35, S38, S39, S40, S42, S44, } \\
\text { S45, S47, S48, S54, S55, S56, S57 }\end{array}$ & 24 \\
\hline & Radiation & $\mathrm{S} 11, \mathrm{~S} 23, \mathrm{~S} 25, \mathrm{~S} 54, \mathrm{~S} 56$ & 5 \\
\hline & Headache & $\mathrm{S} 1, \mathrm{~S} 12, \mathrm{~S} 37$ & 3 \\
\hline \multirow{3}{*}{$\begin{array}{l}\text { Technical } \\
\text { Problems }\end{array}$} & Waste of time & S5, S32, S38, S39, S41, S47, S48, S54 & 8 \\
\hline & Possibility of malfunction & S33, S35, S37, S47 & 4 \\
\hline & Dependency on electricity & $\mathrm{S} 1, \mathrm{~S} 8, \mathrm{~S} 35$ & 3 \\
\hline \multirow{3}{*}{$\begin{array}{l}\text { Personal } \\
\text { Reasons }\end{array}$} & $\begin{array}{l}\text { One cannot see it from the } \\
\text { desks in the back row. }\end{array}$ & S29, S41, S48, S51, S55 & 5 \\
\hline & $\begin{array}{l}\text { Plain whiteboard is more } \\
\text { practical to use. }\end{array}$ & S38, S39, S40 & 3 \\
\hline & It is distractive. & S27, S53 & 2 \\
\hline
\end{tabular}

As can be seen in Table 4, the majority of the students stated that the interactive whiteboard was harmful to their eyes and to their health because of radiation emission, and that they got a headache following extended usage. Based on these opinions, some of the student opinions forming the health problems theme were exemplified as follows:

S6: "My eyes are damaged because I sit close to the smart whiteboard."

S23: "I think it emits radiation because it is electronic."

S35: "I think my eyesight will deteriorate because I'm close to the interactive whiteboard."

S54: "It hurts our eyes because we look at the light for long and we are amidst radiation. I think these are the negative sides of the smart whiteboard."

On the other hand, some of the students stated that the interactive whiteboard causes waste of time in the mathematics classroom. It is likely to be broken and it will not be of use when the electricity goes out because it is dependent on electricity. The following are some of the opinions that can be considered related to both health and technical problems:

S39: "Deterioration of the eyesight, blurry eyesight when viewed for long and a waste of time until it is turned on are the negative aspects of an interactive whiteboard." 
S9: "Upon looking very closely, your eyes become blurry and you can write inaccurately when writing using the pen of the interactive whiteboard."

Moreover, some other student opinions combined under the personal reasons theme are that it is hard to see the interactive whiteboard from the desks at the rear end of the classroom because it is small, and they become distracted because they cannot follow the interactive whiteboard. There were students who stated that the plain whiteboard was more practical for mathematical operations, while the interactive whiteboard distracted their attention. Some of the opinions related to the personal reasons are as follows:

S29: "Our friends may feel uncomfortable because they can't see the problems clearly from the desks in the back row."

S27: "The smart whiteboard distracts attention too much, so you can't concentrate."

S35: "I prefer the plain whiteboard. The interactive whiteboard may sometimes malfunction. Sometimes it doesn't run because the electricity goes out."

One of the important findings obtained in this study, which investigates what students think about learning mathematics with the help of technology (using the interactive whiteboard), is to include students' opinions in the negative perception component, which is not among the components of the TAM3 model. As it can be seen from the findings, the individuals mentioned that there are negative perceptions that could prevent health problems, technical problems and the use of technology due to personal reasons. In order for these negative perceptions to be eliminated, the interactive whiteboard producers must be informed and users should be provided with the necessary precautions.

\section{CONCLUSION AND RECOMMENDATIONS}

In support of the opinions given by the students in the research, a study by Cogill (2002) reported that interactive whiteboards facilitate information transfer and enable students to construct information, allow delivering a presentation using images and have advantages such as facilitation of asking questions and discussing the answers, reinforcing the subjects, giving feedback and enriching the course via the internet. The findings achieved in the research are in consistency with the results of other studies which found that students enjoy using the interactive whiteboard in the classroom, they are more motivated towards the course and feel more interested in the course (Alexiou Ray, 2006; Glover \& Miller, 2001; Sunkur, Şanlı \& Arabac1, 2011). Another result obtained in these studies is that interactive whiteboards ensure students' effectual engagement and participation in the classroom, as found in this research too.

As regards perceived ease of use, similar to the findings of this research, Klammer, Newman, Farrell, Bilezikjiann \& Landay (2001) concluded that interactive whiteboards enable teachers to present the materials they prepare and use several elements via the internet in terms of the ease of using interactive whiteboards. Moreover, similar to the findings of this research, Adıgüzel, Gürbulak and Sarıçayır (2011) stated in their research that these whiteboards enable students to experience the feeling of interacting 
by touching and it is easy to use the interactive whiteboard due to its resemblance to the computer.

As regards perceived usefulness, there are studies in the literature regarding how interactive whiteboards contribute to meaningful learning and how it ensures effectual engagement in the class (Altınçelik, 2009) to facilitate learning and how students understand the subjects better (Gillen et al., 2006; Preston \& Mowbray, 2008). In addition, the students asserted that the interactive whiteboard makes mathematics more fun and enjoyable, increasing their mathematical achievements. There are similar studies in the literature showing that interactive whiteboard provides significant learning (Lipton \& Lipton, 2010) and increases academic achievement (Akçayır, 2011). Finally, some other student opinions on the benefits of an interactive whiteboard in the mathematics classroom were combined under the system characteristic theme. The opinions combined under this theme are facilitating solving more problems and in detail, saving time due to faster instruction. In the research conducted by Adıgüzel, Gürbulak and Sarıçayır (2011), it was stated that one of the benefits of interactive whiteboards was that it was time-saving as its use enabled faster instruction.

As for perceived negativities, there are parallel findings reported in the literature, such as the malfunction of the interactive whiteboard, the waiting time before it is turned on, technical failures and distraction (Altınçelik, 2009; Hall \& Higgins 2005). Yet, these opinions are less frequently reported than the ones in the categories of perceived ease of use or perceived usefulness. In the light of these findings, it is recommended that certain precautions be taken to eliminate these problems and interactive whiteboards are kept in the classrooms for use by teachers and students.

When considering participants' opinions about possible benefits of the use of the interactive whiteboards for teachers, they reported that interactive whiteboards facilitate the job of teachers and teachers can make more effective presentations with the help of visual and audio elements. They also stated that it is time-saving because it does not require drawing some shapes or writing wrong problems. Similarly, Bilici (2011) revealed that teachers think that the interactive whiteboard makes classes more effective and efficient, facilitates instruction and saves time. Thus, some recommendations can be made in accordance with the results achieved in the present research.

Despite the negative opinions regarding the use of the interactive whiteboard during the learning and teaching process, the efficient use of interactive whiteboards should be popularized in the mathematics classrooms because the students provided rather positive opinions on the components of TAM3.

Teachers should be provided with the competence of using interactive whiteboards because the students stated that their friends may lose time when their teachers cannot use the interactive whiteboard professionally.

Since the participants asserted that using interactive whiteboards affects eye health negatively and causes headaches, manufacturers of the interactive whiteboards placed in the classrooms within the framework of the FATIH project should take precautions to eliminate or, at least, mitigate these limitations. 
Finally, it is suggested that long-term and multi-dimensional evaluation activities should be planned and carried out in other classes that cause learning difficulties, such as those in mathematics.

\section{REFERENCES}

Adıgüzel, T., Gürbulak, N., \& Sarıçayır, H. (2011). Akıllı tahtalar ve öğretim uygulamaları. Mustafa Kemal Üniversitesi Sosyal Bilimler Enstitüsü Dergisi, 8(15), 457-471.

Akçayır, M. (2011). Akıllı tahta kullanılarak işlenen matematik dersinin sınıf ögretmenliği birinci sınıf ögrencilerinin başarı, tutum ve motivasyonlarına etkisi. (Unpublished master thesis). Gazi Üniversitesi, Ankara.

Alexiou-Ray, J. (2006). Benefits of the one-to-one ratio on learning: Parental perceptions and student attitudes. Retrieved March 5, 2017 from: https://www.iste.org/Content/Research

Altıçelik, B. (2009). İlköğretim düzeyinde ögrrenmede kalıcllı̆̆ ve motivasyonu sağlaması yönünden akillı tahtaya ilişkin öğretmen görüşleri. (Unpublished master thesis). Sakarya Üniversitesi, Sakarya.

Beauchamp, G. (2004). Teacher use of the interactive whiteboard in primary schools: Towards an effective transition framework. Technology, Pedagogy and Education, 13(3), 327-348.

Berg, B. L. (2001). Qualitative research methods social sciences. Boston: Allyn and Bacon.

Bilici, A. (2011). Öğretmenlerin bilişim teknolojileri cihazlarının eğitsel băglamda kullanımına ve eğitimde Fatih projesine yönelik görüssleri: Sincan Il Genel Meclisi I.Ö.O. Örneği. Paper presented at the meeting of V. International Computer \& Instructional Technologies Symposium, Elazığ.

Bunch, J. C., Robinson, J. S., \& Edwards, M. C. (2012). Measuring the relationship between agriculture teachers' self-efficacy, outcome expectation, interest, and their use of interactive whiteboards. Journal of Agricultural Education, 53(1), 67-80.

Cogill, J. (2002). How is the interactive whiteboard being used in the primary school and how does this affect teachers and teaching. Retrieved March 5, 2017 from: http://www.activewhiteboards.co.uk/ifs_interactive_whiteboards_in_the_primary_school.pdf

Çoklar, A. N., \& Tercan, İ. (2014). Opinions of teachers toward the use of smart boards. Elementary Education Online, 13(1), 48-61.

Davis, F. D., Bagozzi, R., \& Warshaw, P. (1989). User acceptance of computer technology: A comparison of two theoretical models. Management Science, 35(8), 9821003.

Davis, F. D. (1989). Perceived usefulness, perceived ease of use, and user acceptance of information technology. MIS Quarterly, 13(3), 319-339. 
Gillen, J., Kleine Staarman, J., Littleton, K., Mercer, N., \& Twiner, A. (2006). A "Learning revolution"? Investigating pedagogic practices around interactive whiteboards in british primary classrooms. Paper presented at the meeting of The AERA Conference, San Frasisco, USA.

Glover, D., \& Miller, D. (2001). Running with technology: The pedagogic impact of the large-scale introduction of interactive whiteboards in one secondary school. Journal of Information Technology for Teacher Education, 10(3), 257-278.

Görhan M. F., \& Öncü, S. (2015). Öğretmen ve idareci gözünde etkileşimli tahta: kullanım kolaylığı ve yarar algısı üzerine bir durum çalışması. Journal of Teacher Education and Educators, 4(1), 53-77.

Hall, I., \& Higgins, S. (2005). Primary school students' perception of interactive whiteboards. Journal of Computer Assisted Learning, 21(2), 102-117.

Hew, K. F., \& Brush, T. (2007). Integrating technology into K-12 teaching and learning: Current knowledge gaps and recommendations for future research. Education Technology Research and Development, 55(3), 223-252.

Keser, H., \& Çetinkaya, L. (2013). Öğretmen ve öğrencilerin etkileşimli tahta kullanımına yönelik yaşamış oldukları sorunlar ve çözüm önerileri. Turkish Studies, 8(6), 377-403.

Klammer, S., R., Newman, M., W., Farrell,R., Bilezikjiann, M., \& Landay, J., A., (2001). The designers outpost: A tangmble interface for collarative web site design. Proceedings of the 14th annual ACM symposium on User interface software and technology. Retrieved March 5, 2017 from: http://portal.acm.org/citation.cfm?id=502350

Lau, I. (2011). Teachers for "Smart Classrooms": The extent of implementation of an interactive whiteboard-based Professional development program on elementary teachers' instructional practices. Interdisciplinary Journal of E-Learning \& Learning Objects, 7, 275-289.

Lipton, M. L., \& Lipton, L. G. (2010) Enhancing the radiology learning experience with electronic white board technology. American Journal of Roentgenology, 194(6), 1547-1551.

Ma, W. W., Andersson, R., \& Streith, K. O. (2005). Examining user acceptance of computer technology: An empirical study of student teachers. Journal of Computer Assisted Learning, 21(6), 387-395.

Menzi, N., Önal, N., \& Çalışkan, E. (2012). Mobil teknolojilerin eğitim amaçlı kullanımına yönelik akademisyen görüşlerinin teknoloji kabul modeli çerçevesinde incelenmesi. Ege Ĕgitim Dergisi, 13(1), 40-55.

Merriam, S. B. (1998). Qualitative research and case study applications in education: Revised and expanded from case study research in education. San Francisco, CA: Jossey-Bass. 
Milli Eğitim Bakanlığı. (2013). Ortaokul matematik dersi (5, 6, 7 ve 8. sinıflar) öğretim programı. Ankara: Devlet Kitapları Müdürlüğü.

Ng, M. W. E., Shroff, R. H., \& Lim, C. P. (2013). Applying a modified technology acceptance model to qualitatively analyse the factors affecting e-portfolio implementation for student teachers' in field experience placements. Issues in Informing Science and Information Technology, 10, 355-365.

Önal, N. (2014). Ortaokul matematik öğretmenlerinin bilişim teknolojileri yeterliliklerine iliş̧kin görüş̧leri. (Unpublished doctoral dissertation). Gazi Üniversitesi, Ankara.

Preston, C., \& Mowbray, L. (2008). Use of SMART boards for teaching, learning and assessment in kindergarten science. Teaching Science, 54(2), 50-53.

Sunkur, M. Şanlı, Ö., \& Arabacı İ.B. (2011). Aklll tahta uygulamaları konusunda ilköğretim II. kademe öğrencilerinin görüşleri (Malatya ili örneği). V. International Computer \& Instructional Technologies Symposium, Firat Üniversitesi, Elazığ.

Teo, T. (2009). Modelling technology acceptance in education: A study of pre-service teachers. Computers \& Education, 52(2), 302-312.

Teo, T. (2010). Examining the influence of subjective norm and facilitating conditions on the intention to use technology among pre-service teachers: A structural equation modeling of an extended technology acceptance model. The Asia-Pacific Education Researcher, 11(2), 253-262.

Teo, T., Ursavaş, Ö. F., \& Bahçekapıll, E. (2012). An assessment of pre-service teachers' technology acceptance in Turkey: A structural equation modeling approach. The Asia-Pacific Education Researcher, 21(1), 191-202.

Turan, A. H., \& Çolakoğlu, B. E. (2008). Yükseköğrenimde öğretim elemanlarının teknoloji kabulü ve kullanımı: Adnan Menderes Üniversitesi'nde ampirik bir değerlendirme. Doğuş Üniversitesi Dergisi, 9(1), 106-121.

Ursavaş, Ö. F. (2014). Öğretmenlerin bilişsim teknolojilerini kullanmaya yönelik davranışlarının modellenmesi. (Unpublished doctoral dissertation). Gazi Üniversitesi, Ankara.

Ursavaş, Ö. F., Şahin, S., \& Mcilroy, D. (2014). Technology acceptance measure for teachers: T-TAM/ Öğretmenler için teknoloji kabul ölçeği: Ö-TKÖ. Eğitimde Kuram ve Uygulama, 10(4), 885-917.

Venkatesh, V., \& Bala, H. (2008). Technology Acceptance Model 3 and a research agenda on interventions. Decision Sciences, 39(2), 273-315.

Venkatesh, V., \& Davis, F. D. (2000). A theoretical extension of the technology acceptance model: Four longitudinal field studies. Management Science, 46(2), 186-204. 
Venkatesh, V., Morris, M. G., Davis, G.B., \& Davis F. D. (2003). User acceptance of information technology: Toward a unified view. Management Information Systems Quarterly, 27(3), 425-478.

Yıldırım, A., \& Şimşek, H. (2008). Sosyal bilimlerde nitel araştırma yöntemleri. Ankara: Seçkin

Yin, R. K. (2003). Case study research: Design and methods. Beverly Hills, CA: Sage Publication.

\section{Turkish Abstract \\ Matematik Dersinde İnteraktif Tahta Kullanımı: Teknoloji Kabul Modeli Çerçevesinde Öğrencilerin Algıları}

$\mathrm{Bu}$ araștırmanın amacı, öğrencilerin matematik dersinde interaktif tahta kullanılmasına ilișkin algılarını Teknoloji Kabul Modeli çerçevesinde ortaya koymaktır. Bulgulara göre, katılımcıların interaktif tahtanın matematik dersinde kullanılmasına yönelik olumlu algılara sahip oldukları ortaya çıkmıştır. İnteraktif tahta kullanımının özellikle, öğrencilerin dersi daha iyi anlamalarını sağladığı, öğrencilerin sınıfta anlamlı öğrenme ve etkili etkileşimde bulunmalarına, öğrencilerin konsantrasyonlarının artmasına ve zamandan tasarruf etmelerinin sağlanmasına katkıda bulunduğu için yararlı bulunduğu ortaya çıkmıştır. Bu bağlamda katılımcıların interaktif beyaz tahtanın kullanımını yararlı ve kolay bulduğu sonucuna varılmıștır.

Anahtar Kelimeler: mathematics, interactive whiteboard, technology acceptance model (TAM)

\section{French Abstract \\ Utilisation de tableau blanc interactif dans la salle de classe de mathématiques: les perceptions d'Étudiants dans le cadre du Modèle Technologique D'acceptation}

Le but de la recherche présente était de révéler les perceptions des étudiants quant à l'utilisation du tableau blanc interactif dans la salle de classe de mathématiques dans le cadre du Modèle Technologique D'acceptation. Basé sur les conclusions, il a été révélé que les participants avaient les perceptions positives de l'utilisation du tableau blanc interactif dans la salle de classe de mathématiques. Spécifiquement, ils l'ont trouvé avantageux parce qu'il a permis aux étudiants de mieux comprendre le cours, a permis aux étudiants à engagé dans l'apprentissage significatif et l'engagement efficace dans la salle de classe, la concentration des étudiants accrus et a gagné du temps. Il a été conclu que les participants ont trouvé l'utilisation du tableau blanc interactif utile et facile.

Mots Clés: mathématiques, tableau blanc interactif, modèle technologique d'acceptation (TAM) 


\section{Arabic Abstract}

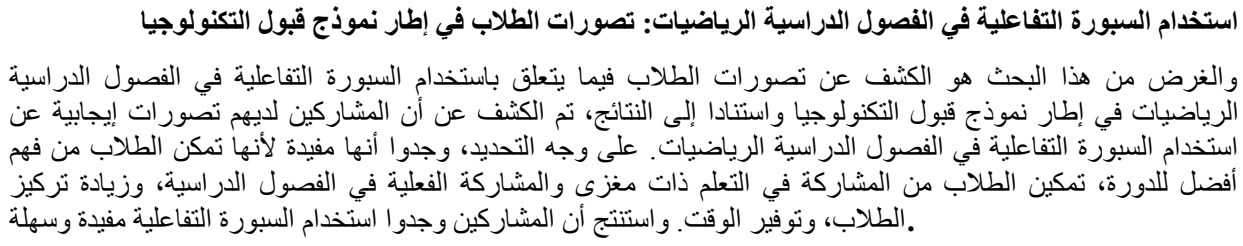

الكلمات الرئيسية: الرياضيات، السبورة التفاعلية، نموذج قبول التكنولوجيا (TAM)

German Abstract

Einsatz von interaktiven Whiteboards im Mathematik-Klassenzimmer: Schülerwahrnehmungen im Rahmen des Technologieakzeptanzmodells

Der Zweck der vorliegenden Forschung war es, die Wahrnehmung der Schüler in Bezug auf die Verwendung des interaktiven Whiteboards im Mathematik-Klassenzimmer im Rahmen des Technologieakzeptanzmodells zu vermitteln. Basierend auf den Ergebnissen zeigte sich, dass die Teilnehmer positive Wahrnehmungen über die Verwendung des interaktiven Whiteboards im Mathematik-Klassenzimmer hatten. Speziell fanden sie es vorteilhaft, weil es den Schülern ermöglichte, den Kurs besser zu verstehen, den Schülern die Möglichkeit zu geben, sinnvolles Lernen und effektives Engagement im Klassenzimmer zu vermitteln, die Konzentration der Schüler zu erhöhen und Zeit zu sparen. Es wurde festgestellt, dass die Teilnehmer die Verwendung der interaktiven Whiteboard nützlich und einfach fanden.

Schlüsselwörter: mathematik, interaktives whiteboard, technologieakzeptanzmodell (TAM) 


\section{Malaysian Abstract \\ Penggunaan papan putih interaktif dalam kelas matematik: Persepsi pelajar dalam rangka Model Penerimaan Teknologi}

Tujuan penyelidikan ini adalah untuk mendedahkan persepsi pelajar tentang penggunaan papan putih interaktif dalam kelas matematik dalam rangka Model Penerimaan Teknologi. Berdasarkan penemuan ini, didapati bahawa peserta mempunyai persepsi positif terhadap penggunaan papan putih interaktif dalam kelas matematik. Khususnya, mereka mendapati ia memberi manfaat kerana ia membolehkan pelajar memahami dengan lebih baik kursus ini, membolehkan pelajar terlibat dalam pembelajaran bermakna dan penglibatan berkesan di dalam bilik darjah, peningkatan kepekatan pelajar, dan masa yang disimpan. Kesimpulannya, peserta mendapati penggunaan papan putih interaktif berguna dan mudah.

Kata Kunci: matematik, papan putih interaktif, model penerimaan teknologi (TAM)

\section{Russian Abstract \\ Использование Интерактивной Доски в Классе Математики: Восприятие Учащихся в Рамках Модели Принятия Технологий}

Цель настоящего исследования состояла в том, чтобы выявить восприятие учащихся относительно использования интерактивной доски в классе математики в рамках Приемочной Модели Технологии. Основываясь на полученных результатах, выяснилось, что у участников сложилось позитивное представление об использовании интерактивной доски в классе математики. В частности, они сочли это полезным, потому что это позволило учащимся лучше понять курс, позволило студентам участвовать в значительном обучении и эффективном участии в классе, увеличить концентрацию внимания учащихся и сэкономить время. Был сделан вывод о том, что участники сочли использование интерактивной доски полезным и легким.

Ключевые Слова: математика, интерактивная доска, модели принятия технологий 